\title{
STRATEGI PEMERINTAH DALAM MENGURANGI ANGKA KEMATIAN IBU (AKI) MELAHIRKAN DI KABUPATEN ENREKANG
}

\author{
Ainun Irada Darungan', Abdul Kadir², Nasrul Haq ${ }^{3}$ \\ Universitas Muhammadiyah Makassar \\ e-mail: ainunira@gmail.com
}

\begin{abstract}
This study purposed to find out how the institutionalization of government strategy in reducing maternal mortality rate (AKI) and how to operationalize the government strategy in reducing maternal mortality rate (AKI) in Enrekang Regency. This study used descriptive qualitative research. Data collection techniques were observation, interviews with 5 informants and documentation. Data analysis used interactive analysis models and used 3 types of triangulation in data validation. The results of this study showed that the role of public health midwives in reducing maternal mortality was very important, especially in the role of community empowerment, optimizing Integrated Healthcare Center activities, and leadership roles in public health and health cadres were expected to be able to encourage the community to carry out self-help activities in improving health status. The role of community health workers in empowering cadres was very important by increasing the ability of community knowledge and awareness regarding prevention of maternal mortality in Enrekang Regency
\end{abstract}

Keywords: Government Strategy, Reducing Maternal Mortality Rate

\begin{abstract}
Abstrak
Penelitian ini bertujuan untukmengetahui bagaimana pelembagaan strategi pemerintah dalam mengurangi angka kematian (AKI) melahirkan di Kabupaten Enrekang serta bagaimana operasionalisasi strategi pemerintah dalam mengurangi angka kematian ibu (AKI) melahirkan di Kabupaten Enrekang. Jenis penelitian yang digunakan adalah penelitian deskriptif kualitatif Informan yang digunakan dalam penelitian ini sejumlah 5 orang dengan teknik pengumpulan data observasi, wawancara dan dokumentasi. Analisis data menggunakan model analisa interaktif serta menggunakan 3 jenis triangulasi dalam pengabsahan data. Berdasarkan hasil penelitian Peran Bidan tenaga kesehatan masyarakat dalam penurunan angka kematian ibu, sangat diperlukan terutama pada peran pemberdayaan masyarakat, optimalisasi kegiatan posyandu, dan peran kepemimpinan dalam kesehatan masyarakat serta Kader kesehatan diharapkan mampu menggerakkan masyarakat untuk melakukan kegiatan swadaya dalam upaya peningkatan derajat kesehatan. Peran petugas kesehatan masyarakat dalam pemberdayaan kader sangat penting dengan meningkatkan kemampuan pengetahuan dan kesadaran masyarakat menegnai pencegahan Angka Kematian Ibu di Kabupaten Enrekang
\end{abstract}

Kata Kunci :Strategi Pemerintah, Mengurangi Angka Kematian Ibu (Aki)

\section{PENDAhULUAN}

Kesehatan merupakan hal yang sangat penting bagi manusia hal ini berkaitan dengan kemajuan sebuah negara.Semakin menjadi baik tingkat kesehatan masyarakat di sebuah negara,maka produktivitas masyarakat sangat berperan dalam memajukan suatu negaranya maka hasilnya akan semakin maksimal.Untuk itu,negara Indonesia berusaha semaksimal mungkin kesehatan masyarakatnya terjaga. Dalam upaya ini pemerintah mengeluarkan UU No 36 Tahun 2009 mengenai
Kesehatan,Dalam pasal 1 ayat 11 disebutkan bahwa dalam Upaya kesehatan ialah setiap sebuah kegiatan atau serangkain kegiatan yang dibuat secara terintegrasi, terpadu dan secara berkesinambungan untuk merawat dan untuk meningkatkan lebihtinggi derajat kesehatan masyarakat sebagai bentuk, pencegahan penyakit, pengendalian penyakit, peningkatan kesehatan, pengobatan dan pemulihan kesehatan masyarakat oleh pemerintah atau masyarakat.Ada beberapa masalah kesehatan yang perlu penanganan serius dari 
pemerintah,salah satu diantaranya adalah angka kematian ibu (AKI) melahirkan.

Di Kabupaten Enrekang, jumlah ibu meninggal pada tahun 2015 sebanyak 5 orang dan pada tahun 2016 meningkat menjadi 8 orang dengan persentasi tertinggi disebabkan karena adanya perdarahan, eklampsia, dan juga infeksi. Berbagai upaya sudah dibuat untuk menekan angka kematian ibu, diantaranya melalui pengadaan bidan di setiap desa, pemberdayaan keluarga serta masyarakat dengan bentuk Buku Kesehatan Ibu dan Anak (Buku KIA) dan Program Perencanaan Persalinan dan Pencegahan Komplikasi (P4K), dan juga penyediaan fasilitas-fasilitas kesehatan Pelayanan Obstetri Neonatal Emergensi Dasar (PONED) di Puskesmas perawatan dan Pelayanan Obstetri Neonatal Emergensi Komprehensif (PONEK) di Rumah Sakit.

Angka kematian ibu (AKI) menjadi perhatian serius pemerintah kabupaten Enrekang,Tahun 2015 kasus kematian ibu melahirkan dari 5 kasus per 500 kelahiran menjadi 8 kasus pada tahun 2016. Angka ini cukup tinggi untuk ukuran kabupaten Enrekang.Sejak tahun 2013, pemerintah kabupaten Enrekang melalui Dinas Kesehatan mengupayakan penurunan AKI.Akan tetapi upaya tersebut belum mendapat hasil yang maksimal.

Strategi adalah salah satu perangkat untuk mencapai tujuan. Secara umum,strategi merupakan penentuan rencana para pemimpin tertinggi yang berfokus pada suatu tujuan dalam jangka panjang sebuah organisasi,disertai penyusunan suatu upaya atau cara bagaimana supaya tujuan tersebut dapat digapai. Sedangkan pengertian strategi secara khusus adalah merupakan tindakan yang bersifat incremental (senantiasa mengikat) dan terus-menerus,serta dibuat berdasarkan sudut pandang mengenai apa yangdinginkan para pelanggan dimasa akan datang.Dengan demikian,strategi hampir selalu dari apa yang dapat terjadi dan bukan diawali dari apa yang terjadi. Dalam perkembangannya, konsep tentangteori strategi teruslah berkembang. Hal ini dapat dilihatdengan adanya perbedaan konsep terkait strategi. Beberapa pendapat terkait strategi oleh pakar sebagai berikut :

Menurut Suwarsono (2010:86) mengatakan strategi pengembangan adalah suatu strategi dikatakan sebagai strategi pengembangan jika secara organisasi mendesain strategi yang hendak meningkatkan status,kapasitas dan sumber daya pada ujungnyaakan melahirkan postur organisasi yang baru yang berbeda dimasa akan datang.

Menurut Jaunch Saladin, (2003:54) Defenisi strategi sebuah rencana yang disatukan,luar dan terintegritas yang menghubungkan dan yang direncanakan untuk memastikan tujuan utama dapat tercapaidengan melalui pelaksanaan yang benar dan tepat oleh organisasi.Beberapa faktor yang penting dalam strategi.

Pertanyaan diatas juga didukung oleh Umar, (2002:43) menjelaskan senidan ilmu dalam menggunakan kemampuan sumber daya dan lingkungan secara efektif yang terbaik.Terdapat unsur yang penting dalam pengertian strategi yaitu kemampuan sumber daya,lingkungan,dan tujuan rumusan strategi memberikan informasi mengenai apa yang diperbuat dan kenapa dilakukan demikian siapa yang akan bertanggung jawab dan mengoprasikan,berapa besar biaya dan lama waktu pelaksanaan,serta hasil apa yang diperoleh.

Menurut Kuncoro (2004) strategi berkaitan dengan suatu keputusan Besar yang diperhadpakan pada organisasi dalam melakukan bisnis, yakni suatu keputusan yang dapat menentukan kesuksesan dan kegagalan sebua organisasi. Penekanan pada pola Kerangka Kerjadan Pola Tujuanmenekankan bahwa strategi berkaitan dengan perilaku yang konsisten,maksudnya ketika suatu strategi "Menetapkan bahwa keputusan strategi yang dibuat perusahaan seharusnya "Menyatakan bahwa keputusan strategi yang dibuat perusahaan seharusnya mampu menciptakan keunggulan yang kompetitif bagi perusahaan, dan nantinya yang menetukan sukses atau tidak perusahaan yang ada dalam lingkungan yang kompetitif.

Menurut Marrus (2002) dalam buku,Husain Umar. Dalam strategi manajemen sangat dibutuhkan In Action. Mendefinisikan strategi ialah suatu proses penetapan rencana para pemimpin tertinggi yang berkonsentrasi pada tujuan jangka yang panjang dan arah tindakan untuk mencapai arah dan tujuan yang akan dicapai tersebut. Dapat dijelaskan dengan adanya strategi pada setiap tindakan yang akan dijalankan dapat berguna sebagai petunjuk 
jalan harus seperti apa untuk mencapai tujuan yang ditetapkan diawal.

Menurut S.P. Siagian (2004:16) definisi klasik tentang stategi yang semula berasal dari kalangan militer mengatakan bahwa strategi adalah cara terbaik untuk mempergunakan dana, daya dan peralatan yang tersedia untuk memenangkan sebuah peperangan. Definisi demikian biasanya dibuat untuk membedakan dengan taktik yang diartikan sebagai cara untuk mengerahkan tenaga, daya, dana dan peralatan yang dimiliki untuk memenangkan pertempuran. Terlihat dalam kedua defenisi tersebut bahwa suatu pasukan yang ditugaskan untuk menghadapi serangan ,ancaman dan gangguan dari musuh.Ditetapkan dalam organisasi-organisasi non militer, Strategi berkaitan dengan masalah-masalah yang menyangkut efisiensi.

Menurut Asmoko (2010:45) strategi pemerintah ialah menghubungkan antara konsep manajemen strategi pada sector privat dengan aturan pengelolaan PEMDA yang ada didalam perundang-undangan di Indonesia. Terkait Pembahasan ini dilakukan dengan cara mengkaji literatur tentang manajemen strategi dan konsep manajemen strategi yang terdapat dalam peraturan undang-undang di Indonesia mengenai pengelolaan pemerintah,setelah itu akan akan diuraikan alternatif pendekatan manajemen strategi agar dapat diterapkan pada pemerintah di Indonesia.

Menurut Kotler $(2008 ; 25) \quad$ strategi pemerintah merupakan proses manajerial agar mengembangkan dan menjaga keserasian antara tujuan pemerintah dalam peluang pasar yang berubah-ubah,dengan tujuan agar membentuk dan menyesuaikan usaha pemerintah dan produk yang dihasilkan bisa mencpai tingkat perubahan.

Berdasarkan berbagai pendapat tersebut,dapat disimpulkan bahwasanya dalam penyusunan strategi wajib memerhatikan sasaran dan tujuan yang ingin dicapai diwaktu yang akan datang, selain itu sebuah organisasi harus mencapaisasaran dan tujuan yang ingin dicapai diwaktu yang akan datang, selain itu sebuah organisasi harus bisa berinteraksi dengan baik dilingkungan yang dimana strategi itu akan dimplementasikan, sehingga strategi itu tidak bertolakbelakang akan tetapi searah serta sesuai dengan kondisi lokasi lingkungan dan melihat kemampuan eksternal dan internal yang meliputi kelemahan dan kekuatan organisasinya. Strategi merupakan perluasan misi guna menjembatangi organisasi dengan sekitar lingkungannya. Strategi biasanya dikembangkan untuk mengatasi masalah isu strategi,dimana strategi menjelaskan respon organisasi pada kebijakan pokok.Strategi memiliki peranan yang sangat penting bagi pencapaian tujuan dalam suatu lingkungan organisasi,karena strategi memberikan arah tindakan dan cara bagaimana tindakan tersebut harus dilakukan agar tujuan yang diharapkan tercapai.

Pemerintah sebagai sebuah organisasi ditinjau dari sudut biological adalah sebuah organisme yang hidup dari setiap organisme mempunyai bagian yang mempunyai kepala(head) sebuah tubuh manusia atau hewan yang dikendalikan oleh kepalanya sebuah rumah tangga dikendalikan oleh kepala keluarga .Kepala dapat dianggap identik dengan pemerintah baik itu pemerintah pusat maupun pemerintah daerah,Dimana pemerintah pusat adalah Presiden Republik Indonesia yang memegang kekuasaan pemerintahan Republik Indonesia yang dibantu oleh Wakil Presiden dan MenteriMenteri Negara, sedangkan pemerintahan Daerah adalah kepala daerah sebagai unsur penyelenggaraan pemerintahan Daerah yang memimpin pelaksaan urusan pemerintahan yang menjadi kewenangan daerah otonom, dan pemerintah daerah adalah penyelenggaraan urusan pemerintah oleh pemerintah daerah Kabupaten/kota menurut asas otonomi dengan seluas-luasnya dalam sistem dan prinsip Negara Kesatuan Republik Indonesia.

Pemerintah adalah proses penetapan janji dan legitimasi seorang pejabar Negara/Publik diukur dengan fakta, sejauh mana ia menebar janji, demikian menurut Ndraha (2003) yang baik bersifat internal maupun kepada masyarakat umum.Sedangkan menurut Delly Mustafa (2013) mengemukakan bahwa pemerintah adalah keseluruhan struktur, lembaga dan unit-unit dalam Negara yang bertugas untuk mengatur pelaksanaan tugastugas pemerintahan.

Menurut International Statistical Classification of Disease,Injuries and Causes of Death, Edisi X (ICD-X, WHO), kematian ibu adalah kematian seorang wanita yang terjadi selama kehamilan, sampai dengan 42 hari setelah berakhirnya kehamilan, tanpa memperhatikan lama dan tempat terjadinya 
kehamilan, yang disebabkan oleh atau dipicu oleh kehamilannya, atau penanganan kehamilannya, tetapi bukan karena kecelakaan (Syafrudin dan Hamidah, 2009).

Indikator yang umum digunakan dalam kematian ibu adalah AKI atau Maternal Mortality Ratio (MMR).Defenisi AKI adalah jumlah ibu yang meninggal selama kehamilan, bersalin dan nifas yang dikarenakan oleh faktor kehamilannya per 100.000 kelahiran hidup (Kemenkes, 2010).Angka ini mencerminkan risiko obstetri yang dihadapi seorang ibu sewaktu dia hamil.Jika ibu hamil beberapa kali maka risikonya meningkat, dan digambarkan sebagai risiko kematian ibu sepanjang hidupnya, yaitu probabilitas menjadi hamil dan probabilitas kematian karena kehamilan sepanjang masa reproduksi.

Selain hal tersebut di atas, AKI juga mencerminkan keberhasilan pembangunan kesehatan suatu negara, merefleksikan status kesehatan ibu selama hamil dan nifas, kualitas pelayanan kesehatan serta kondisi lingkungan sosial dan ekonomi (Kemenkes, 2010).16 kematian ibu per 100.000 kelahiran hidup dan negara berkembang melaporkan 240 kematian ibu per 100.000 kelahiran hidup (WHO, 2012).

\section{METODE PENELITIAN}

Penelitian ini dilakukan dan direncanakan berlangsung selama 2 bulan.Lokasi Penelitian dilakukan di Dinas Kesehatan Kota Enrekang Karena Ingin mengetahui strategi pemerintah yang terkait, yaitu Dinas Kesehatan Kota Enrekang terkait mengurangi angka kematian ibu (AKI) melahirkan.

Penelitian ini menggunakan metode penelitian kualitatif dengan menjelaskan secara jelas masalah sesuai dengan objek penelitian dariberdasarkan realita/fakta yang didapatdilapangan . Menurut Bogdan dan Taylor (dalam Moleong, 2002), bahwa metode penelitian kualitatif sebagai suatu prosedur dalam penelitian yang melahirkan data deskriptif berupa fakta-fakta lisan atau tertulis dari sebagian orang dan perilaku sikap yang dapat kita amati.

Informan yang ada dalam penelitian ini yaitu orang-orang yang berhubungan langsung dalam strategi pemerintah dalam hal ini Kota Enrekang terkait mengurangi angka kematian ibu (AKI).dengan tujuan dan pertimbangan tertentu yang dilandasai dengan syarat-syarat ilmiah.

Adapun informan dari penelitian ini bedasarkan judul di atas yakni Kepala Dinas Kesehatan Kota Enrekang, Bidan Puskesmas, Perawat Rumah Sakit dan Masyarakat.

Analisis data ialah langkah selanjutnya untuk mengelola data dimana data yang diperoleh, dikerjakan dan dimanfaatkan sedemikian rupa untuk menyimpulkan persoalan yang diajukan dan menyusun hasil penelitian.Teknik analisis data yang dipakai dalam penelitian ini yaitu analisis data kualitatif yang diartikan sebagai usaha analisis berdasarkan kata-kata yang disusun kedalam bentuk teks yang diperluas.

Analisis data dilakukan secara deskriptif kualitatif yang bertujuan untuk deskripsi secara sistematis, akurat dan factual tentang sifat-sifat dan fakta-fakta dari fenomena yang diselidiki Miles dan Huberman, dalam(Sugiyono,2012:91)

\section{HASIL DAN PEMBAHASAN}

Kabupaten Enrekang adalah salah satu Daerah Tingkat II di provinsi Sulawesi Selatan, Indonesia. Ibu kota kabupaten ini terletak di Kota Enrekang. Kabupaten ini memiliki luas wilayah $1.786,01 \mathrm{~km}^{2}$ dan berpenduduk sebanyak \pm 190.579 jiwa. Kabupaten Enrekang dengan ibukota Enrekang terletak $\pm 235 \mathrm{Km}$ sebelah utara Makassar. Secara geografi Kabupaten Enrekang terletak pada koordinat antara $3^{\circ} 14^{\prime}$ 36" sampai $3^{\circ}$ 50' 00" Lintang Selatan dan $119^{\circ} 40^{\prime}$ 53" sampai $120^{\circ} 06$ ' 33" Bujur Timur. dengan luas wilayah sebesar 1.786,01 $\mathrm{Km}^{2}$.

Melihat dari kondisi sosial budaya tersebut, maka beberapa masyarakat menganggap perlu adanya penggantian nama Kabupaten Enrekang menjadi Kabupaten Massenrempulu',meskipun saat ini belum diakui oleh pemerintah sebagai salah satu suku yang ada diSulawesi Selatan.Suku ini terdiri dari tiga Etnis yang memiliki ciri khas dan bahasa yang berbeda.Ketiga Etnis ini adalah Etnis Duri,Etnis Enrekang dan Etnis Maiwa.Etnis Duri yang mendiami wilaya bagian utara kabupaten Enrekang yang terdiri dari 8 Kecamatan yaitu: Kecamatan Alla, Anggeraja, Baraka, Curio, Baroko, Masalle, Malua dan Buntu Batu.Budaya dan adat 
istiadat etnis ini hampir sama dengan suku Tanah Toraja dan bahas yang digunakan adlah Bahasa Duri.Etnis Enrekang mendiami wilayah bagian tengah Kabupaten Enrekang sampai ke daerah Suppa, Letta dan Batu Lappa di Kabupaten Pinrang,terdiri dari 2 Kecamatan yaitu Kecamatan Enrekang dan Cendana.Budaya dan adat istiadat hamper sama dengan budaya dan adat istiadat Suku Bugis.adapun bahasa yang digunakan adalah Bahasa Toponjo.Etnis yang ketiga adalah Etnis Maiwa yang mendiami bagian selatan selatan Kabupaten Enrekang yang terdiri dari 2 Kecamatan yaitu Kecamatan Kecamatan Maiwa dan Bungin,dimana budaya dan adat istiadatnya menyerupai Suku Bugis tetapi bahasa yang digunakan adalah Bahasa Bungin

Operasional Strategi sebagai petunjuk bagi setiap manajer operasional beserta bawahan dalam mengambil setiap keputusan operasional dalam rangka pelaksanaan berbagai strategi yang sudah ditentukan oleh Pemerintah pada tingkat lebih tinggi, untuk itu strategi dapat diukur dengan melihat sebagai berikut:

\section{Bidang Keuangan}

Dimaksud Bidang Keuangan disini yaitu dukungan atau kontribusi seumber daya ataupun sarana dan prasarana untuk dinas kesehatan dari lembaga pemerintah atau lembaga lain yang ikut serta dalam dukungan mengenai program menekan angka kematian ibu melahirkan di Kabuaten Enrekang.

Berdasarkan hasil wawancara dengan informan di atas yang jika disesuaikandengan teori Menurut S.P.Siagian (2004:16); Dalam strategi keuangan harus bisa menentukan arah pemakaian dana yang tersedia untuk mendukung strategi,baik untuk kepentingan jangka panjang. Selanjutnya berdasarkan yang terjadi dan apa yang disampaikan oleh informan di atas bahwa untuk terkait dengan anggaran dana yang dikeluarkan untuk program pemerintah dalam menekan angka kematian ibu melahirkan, telah ditur oleh pemerintah pusat maupun pemerintah daerah dalam sumber pembiayaan kesehatan yang berasal dala dana APBN, APBD dan PALN sehingga dalam pelaksanaannya mengacu pada aturan masing-masing porsi dari pemerintah pusat maupun dari pemerintah daerah Kabupaten Enrekang.
Berdasarkan hasil wawancara dengan informan di atas yang jika disesuaikandengan teori Menurut S.P.Siagian (2004:16); Dalam strategi keuangan harus bisa menentukan arah pemakaian dana yang tersedia untuk mendukung strategi,baik untuk kepentingan jangka panjang. Selanjutnya berdasarkan yang terjadi dan apa yang disampaikan oleh informan di atas bahwaseiring dengan jalannya program kesehatan ini memang terlihat perbedaan ibu yang melahirkan saat sebelum dan adanya program ini, sebelum adanya program ini yaitu ibu-ibu yang dulunya hanya melahirkan dirumah sangat rentan terjadinya kesalahan dalam proses melahirkan karena hanya dibantu oleh dukun/orang pintar dengan menggunakan alat bantu seadanya atau tanpa menngunakan bidan atau jauh dari kelengkapan alat medis dan ini sangat beresiko bagi kesehatan ibu ang melehirkan.

\section{Bidang Penelitian Pengembangan}

Yang dimaksud disini adalah berbagai kegiatan penelitian dan pengembangan membuahkan hasil yang mendukung implementasi strategi perencanaan dalam menekan angka kematian ibu melahirkan di Kabupaten Enrekang.

Berdasarkan hasil wawancara dengan informan di atas yang jika disesuaikandengan teori Menurut S. P. Siagian (2004:16); Agar berbagai kegiatan penelitian dan pengembangan membuahkan hasil yang mendukung implementasi strategi induk suatu instansi,ada beberapa hal yang perlu diperhitungkan yang berarti dalam strategi ditekankan upaya yang sifatnya inovatif yang diharapkan mengakibatkan terjadinya berbagai terobosan. Selanjutnya berdasarkan yang terjadi dan apa yang disampaikan oleh informan di atas bahwa untuk meliaht bagaimana pemerintah dalam meningktakan pengembangan dan penelitiannya terkait dengan angka kematian ibu melahirkan yaitu terkait dengan apa yang disampaikan diatas bahwa dalam pelaporan dan keteranga angka kematian ibu terkait kendala dan apa saja dan penyebab apa saja yang harus diperbaiki dalam upaya mensukseskan program kesehatan ini upayanya yaitu dari bidan-bidan yang dikirim kepelosok-pelosok desa rutin melaporkan kepusat dalam hal ini Dinas kesahatan terkait kendala dan kekuranga dan 
penyebab yang dapat menggangu proses persalianan ibu yang melahirkan didaerah desanya masing-masing.

Berdasarkan hasil wawancara dengan informan di atas yang jika disesuaikandengan teori Menurut S.P.Siagian (2004:16); Agar berbagai kegiatan penelitian dan pengembangan membuahkan hasil yang mendukung implementasi strategi induk suatu instansi,ada beberapa hal yang perlu diperhitungkan yang berarti dalam strategi ditekankan upaya yang sifatnya inovatif yang diharapkan mengakibatkan terjadinya berbagai terobosan. Selanjutnya berdasarkan yang terjadi dan apa yang disampaikan oleh informan di atas bahwa untuk penanganan masalah ibu melahirkan betul-betul terus dikontrol oleh bidan ang ditugaskan dimasingmasing desa hal ini juga terlihat dari pemberian tanda berupa bendera dirumah warga yan terdapat ibu hamil didalamnya agar sehingga bisa terus dikontrol oleh Petugas Kesehatan Puskesmas.

Berdasarkan hasil wawancara dengan informan di atas yang jika disesuaikandengan teori Menurut S.P.Siagian (2004:16); Agar berbagai kegiatan penelitian dan pengembangan membuahkan hasil yang mendukung implementasi strategi induk suatu instansi,ada beberapa hal yang perlu diperhitungkan yang berarti dalam strategi ditekankan upaya yang sifatnya inovatif yang diharapkan mengakibatkan terjadinya berbagai terobosan. Selanjutnya berdasarkan yang terjadi dan apa yang disampaikan oleh informan di atas bahwa untuk program ini langkah yang penting adalah melaksanakan sosisalisai dini untuk menghindari hal-hal yang tidak diinginkan bagi kesehatan ibu ang sedang hamil dan akan melairkan.

\section{Bidang Sumber Daya Manusia}

Yang dimaksud disini yaitu ketersediaan tenaga medis yang ada di Kabupaten Enrekang dan Kebutuhan setiap Puskesams atau Rumah Sakit untu program menekan angka kematian ibu melahirkan terlaksana dengan baik.

Berdasarkan hasil wawancara dengan informan di atas yang jika disesuaikan dengan teori Menurut S.P.Siagian (2004:16); Dalam strategi di bidang manajemen sumber daya manusia

(MSDM) menggambarkandengan jelas segala bentuk serta jenis langkah-langkah yang harus diambilditingkat manajemen operasioanal berdasarkan strategi dasar dan filsafat terkait denganMSDM serta telah ditentukan pada tingkat manajemen tertinggi. Selanjutnya berdasarkan yang terjadi dan apa yang disampaikan oleh informan di atas bahwa untuk langkah yang diambil pemerintah yaitu penempatan bidan tidak hanya di puskesmas atau di rumah sakit tetapi penempatan disetiap desa, guna untuk memberikan pelayanan kepada masyarakat desa tersebut, termasuk mengontrol perkembangan ibu hamil dan mengarahkan ibu hamil agar melahirkan dibantu dengan bidan, bukan lagi oleh orangorang yang pintar/dukun.

Berdasarkan hasil wawancara dengan informan di atas yang jika disesuaikan dengan teori Menurut S.P.Siagian (2004:16); Dalam strategi di bidang manajemen sumber daya manusia (MSDM) harus menggambarkandengan jelas segala bentuk serta jenis langkah-langkah yang harus diambilditingkat manajemen operasioanal berdasarkan strategi dasar dan filsafat terkait denganMSDM serta telah ditentukan pada tingkat manajemen tertinggi. Selanjutnya berdasarkan yang terjadi dan apa yang disampaikan oleh informan di atas bahwa untuk sosiaisasi yang sifatnya mencegah terjadinya msalah-maslah kesehatan pada ibu sudah sangat masif dilakukan oleh pemrintah dalam hal ini dinas kesehatan kabupaten enrekang.

Berdasarkan hasil wawancara dengan informan di atas yang jika disesuaikan dengan teori Menurut S.P.Siagian (2004:16); Dalam strategi di bidang manajemen sumber daya manusia (MSDM) harus menggambarkandengan jelas segala bentuk serta jenis langkah-langkah yang harus diambilditingkat manajemen operasioanal berdasarkan strategi dasar dan filsafat terkait denganMSDM serta telah ditentukan pada tingkat manajemen tertinggi. Selanjutnya berdasarkan yang terjadi dan apa yang disampaikan oleh informan di atas bahwa jika dilihat langsung denga fakta apa yang ada dilapangan yang jadi permasalahannya itu dari ibu melahirkan.

Berdasarkan hasil wawancara dengan informan di atas yang jika disesuaikan dengan teori Menurut S.P.Siagian (2004:16); Dalam 
strategi di bidang manajemen sumber daya manusia (MSDM) harus menggambarkandengan jelas segala bentuk serta jenis langkah-langkah yang harus diambilditingkat manajemen operasioanal berdasarkan strategi dasar dan filsafat terkait denganMSDM serta telah ditentukan pada tingkat manajemen tertinggi. Selanjutnya berdasarkan yang terjadi dan apa yang disampaikan oleh informan di atas bahwa untuk aturan pelaranagn melahirkan dirumah sangat serius dalam aturan denda yang dilakukan pemerintah namun disisi lain lokasi ibu yang seharusnya melahirka terbilang cukup jauh untuk diajngkau ibu melahirkan disini terlihta perlunya kesedian bidan untuk turun langsuang ke rumah ibu yang melahirkan walaupun diruamh namun yang menangani sudah bidan yang sesuai, itu sudah cukup alasan untuk melahirkan dirumah.

Dalam hal ini,strategi kelembangaan mempunyai peranan yang cukup penting di karenakan pemerintah daerah yang khususnya Dinas Kesehatan dapat menambah tenaga medis khsusnya bidan yang siap tanggap menanangani ibu melahirkan.Pelembagaan Strategi yang dimaksud adalah Pelembagaan strategi yang lebih menjamin operasionalisasinya dengan tingkat efisien dan efektivitas yang tinggi. Terdapat 3 aspek penting dalam pelembagaan strategi yaitu sebagai

\section{Sruktur Organisasi}

Merupakan struktur yang digunakan untuk mencapai tujuan dan berbagai sasaran dalam menunjang kinerja khususnya program dalam menagnani ibu melahirkan, serta mengemban misi dan mewujudkan suatu strategi melalui berbagai kegiatan operasional Khusunya dalam kegiatan program menekan angka kematian ibu melahirkan di Kabupaten Enrekang.

Dinas Kesehatan dalam Melaksanakan Tugasnya Mempunyai 5 Bagian atau Bidang dan 12 Seksi.Bertolak dari jumlah dan jenis kewenangan aparat Petugas Kesehatan Puskesmas yang diuraikan dalam bentuk tugas pokok dan fungsi sebagai pelayanan public, maka dapat digambarkan sesuai dengan masinmasing tugas dan fungsinya.

Berdasarkan hasil wawancara dengan informan di atas yang jika disesuaikan dengan teori Menurut S.P.Siagian (2004:16); bahwa organisasi merupakan wahana yang digunakan untuk mencapai tujuan dan berbagai sasaran, mengemban misi dan mewujudkan suatu strategi melalui berbagai kegiatan operasional oleh sekelompok orang yang terikat secara formal dalam suatu hubungan antara orangorang yang menduduki jabatan manajerial. Selanjutnya berdasarkan yang terjadi dan apa yang disampaikan oleh informan di atas bahwa untuk Semua stakeholder harus bahu membahu. Menciptakan berbagai inovasi pelayanan kesehatan.Mulai camat, kepala desa harus bersama-sama puskesmas melakukan upaya penurunan ini dengan inovasinya selain itu juga peran atau partisipasi dari ibu yang hamil untuk konsultasi kesehatan rutin di puskesmas, baik yang berisiko maupun tidak,peristiwa kematian ibu saat melahirkan banyak disebabkan oleh pendarahan dan preeklampsia.Penyebab terakhir sendiri, merupakan komplikasi pada kehamilan yang ditandai tekanan darah tinggi. Dan juga terdapat beberapa faktor yang menjadi penyebab kematian terhadap ibu maupun bayi pada saat proses melahirkan diantaranya masih banyaknya proses melahirkan masyarakat ditangani oleh orang yang bukan ahlinya.

\section{Peranan Kepemimpinan}

Peranan kepemimpinan dalam pelembagaan strategi dalam hal ini Dinas Kesehatan Kabupaten Enrekang sangat menentukan dalam implementasi strategi program Pemerintah, khususnya dalam menangani ibu melahirkan ,baik pada tingkat pemerintahan Kota maupun Desa. Peranan pemimipin yang sifatnya interpersonal yang terwujud dalam keberadaannya sebagai symbol organisasi dalam hal mana ia melaksanakan berbagai kegiatan khusunya pada program pemerintah menekan angka kematian ibu melahirkan di Kabupaten Enrekang.

Berdasarkan hasil wawancara dengan informan di atas yang jika disesuaikan dengan teori Menurut S.P.Siagian (2004:16); Kepemimpinan merupakan elemen organisasi yang sangat menentukan dalam implementasi strategi, baik pada tingkat perusahaan maupun pemerintahan. Peranan pemimipin yang sifatnya interpersonal yang terwujud dalam keberadaannya sebagai symbol organisasi 
dalam hal mana ia melaksanakan berbagai kegiatan. Aktivitasnya sebagai penghubung dengan berbagai pihak yang berkepentingan ,baik yang sifatnya internal maupun eksternal.Perananan yang sifatnya informasional melalui mana ia memantau berbagai informasi yang didapat oleh organisasi atau instansi.Dan peranan pemimpin sebagai pengambil keputusan. Selanjutnya berdasarkan yang terjadi dan apa yang disampaikan oleh informan di atas bahwa untuk puskesmas sebagai pemberi pelayanan dasar telah melakukan sejumlah kegiatan yang lebih bersifat pencegahan (preventif) dan terus meningkatkan kualitas pelayanan khususnya pada ibu hamil di wilayah kerjanya. Dengan langkah itu, kasus risiko tinggi dan komplikasi bisa dijaring sedini mungkin, serta bisa dilakukan rujukan terencana dan tepat waktu ke rumah sakit.

\section{Peranan Kultur Organisasi}

Pemerintah Kabupaten Enrekang dalam hal ini Dinas Kesehatan Kabupaten enrekang, mempunyau peranan pentig dalam menjaga kultur organisasi menjadi pengikat dan penekan rasa kebersamaan bagi jajaran anggotanya berkat pemahaman yang sama tentang cara bertindak dan berperilaku dalam menanganiprogram pemerintah dalam menekan angka kematian ibu melahirkan di Kabupaten Enrekang.

Berdasarkan hasil wawancara dengan informan di atas yang jika disesuaikan dengan teori Menurut S.P.Siagian (2004:16); kultur organisasi merupakan makna kehidupan bersamayang tercermin pada berbagai persepsi penting yang meskipun itu tidak dinyatakan secara tertulis ,diakui dan diterima oleh semua pihak dalam organsasi tersebut.Fungsi dari kultur oraganisasi untuk memelihara stabilitas sosial dalam sebuah organisasi ,Artinya kultur menjadi "pengikat" dan penekan rasa kebersamaan bagi anggotanya berkat pemahamanyang sama tentang cara bertindak dan berperilaku. Selanjutnya berdasarkan yang terjadi dan apa yang disampaikan oleh informan di atas bahwa untuk tenaga kesehatan masyarakat sudah berperan aktif dalam menggalakkan kegiatan pemberdayaan masyarakat dibidang kesehatan, kegiatan ini dibantu oleh kader kesehatan yang bersumber dari masyarakat setempat yang dipilih dengan sukarela. Kader yang ada dimasyarakat dapat membantu petugas kesehatan. Kader kesehatan inilah yang menjadi motor penggerak dan pengelola upaya kesehatan primer ditingkat keluarga dan masyarakat. Kader diharapkan mampu menggerakkan masyarakat untuk melakukan kegiatan swadaya dalam upa ya peningkatan derajat kesehatan.

\section{KESIMPULAN}

Berdasarkan hasil penelitian dan pembahasan yang telah dilakukanmengenai Strategi Pemerintah dalam mengurangi angka kematian ibu (AKI) melahirkan di Kabupaten Enrekang, dapat dismipulkan bahwa peran bidang tenaga kesehatan masyarakat dalam penurunan angka kematian ibu, sangat diperlukan terutama pada peran pemberdayaan masyarakat, optimalisasi kegiatan posyandu, dan peran kepemimpinan dalam kesehatan masyarakat. Serta Tenaga kesehatan masyarakat dalam upaya suatu pemberdayaan dapat bermitra dengan baik dengan kader dan tokoh-tpkoh masyarakat dalam upaya penanggulangan angka kematian ibu melahirkan, sehingga masyarakat dapat ikut aktif dalam kegiatan mencegah dan meanggulangi penyebab angka kematian ibu melahirkan.

Kader kesehatan diharapkan mampu menggerakkan masyarakat untuk melakukan kegiatan swadaya dalam upaya peningkatan derajat kesehatan.Peran petugas kesehatan masyarakat dalam pemberdayaan kader sangat penting.Upaya dalam penurunan angka kematian ibu, bayi dan anak, petugas kesehatan wajib bermitra dengan kader, karena kader yang berada didaerah dan dikenal oleh masyarakat setempat.Pembinaan dan pengembangan kader diperlukannya dengan kesukarelaan, karena kader bertugas secara sosial.Akan tetapi tidak berarti seorang kader tidak memerlukan penghargaan baik yang bersifat non-material ataupun yang bersifat material.Oleh karena itu, perlu dikembangkan suatu sistem penghargaan, di mana fungsi sebagai kader merupakan sesuatu yang menimbulkan kebanggaan dan kepuasan.

Kepemimpinan dalam kesehatan masyarakat dapat menjadikan peran tenaga kesehatan masyarakat lebih bermakna.Pemimpin yang tepat dapat berefek pada pembangunan kesehatan.Yang bisa 
menjadikan masyarakat yang mandiri dan berjiwa inovasi dalam mengatasi dan membuat kebijakan dalam penyelesaian masalah angka kematian ibu, dengan meningkatkan kemampuan pengetahuan dan kesadaran masyarakat menegnai pencegahan Angka Kematian Ibu di Kabupaten Enrekang.

\section{DAFTAR PUSTAKA}

Busro, 2018.Teori-Teori Manajemen Sumber Daya Manusia. Pernada Media.

Bambang,Hariadi.(2005).StrategiManajemen.J akarta

Hindri Asmoko. 2010. Evaluasi Sistem Pengukuran Kinerja Pemerintah Pusat Di Indonesia

Marrus, Stephanie K.2012. Strategic Management In Action.PT. Gramedia Pustaka Utama. Jakarta

Mintzberg Henry \& James Brian Quinn.2012.The Strategy Process Concepts and Contexts.NewJerse:Prientice Hall Inc.

Rangkuti, Freddy. 2009. Strategi Promosi Yang Kreatif dan Analisis. Kasus. Integrated Marketing Communication. Jakarta: PT. Gramedia Pustaka Utama.

Makmur. 2009. Teori Manajemen Stratejik Dalam Pemerintahan dan Pembangunan. Bandung: RefikaAditama

Suwarsono.2012.Manajemen Stratejik. Konsep dan Kasus. Edisi Ketiga Yogyakarta.

Siagian Sondang.p. 2004 Manajemen Strategik, Jakarta Bumi Aksara

David,Fred R.2004. Manajemen Strategis, Edisi Bahasa Indonesia, Jakarta, PT. Indeks Kelompok Gramedia

Fibriana,Al.2007. Faktor-Faktor risiko yang mempengaruhi kematian maternal (studi kasus di kabupaten cilacap). (Tesis). Semarang: Program Studi Magister Epidemiologi Universitas Diponegoro.

Mustafa, Delly. 2013. Birokrasi Pemerintahan. Bandung: Alfabeta 